\title{
MAKING AND AUTHENTICATING THE CITIZEN: NATURALISATION AND PASSPORT APPLICATION IN CANADA
}

\author{
Catherine Frost ${ }^{1}$ \& Elke Winter ${ }^{2}$ \\ McMaster University, University of Ottawa
}

\begin{abstract}
How do 'we' know our fellow citizens? This paper considers two processes where recognition occurs in the Canadian context: passports and naturalisation. Using document and policy analysis we argue there are two major forms of knowledge called upon to sort insiders from outsiders. Mechanical knowledge involves tests and evaluations driven by document-matching, biometrics and fact-checking exercises. Moral knowledge concerns the kind of lives we live among our peers and our intentions towards the political community. We note that in the Canadian case tensions exist between expectation and reality around citizen recognition. The state increasingly aspires to know the citizen through procedural checks or material observation yet encounters limitations that require some form of interpersonal knowledge rooted in human-to-human relationships. Drawing on these processes, in conclusion we suggest that how knowledge about citizenship is framed serves to sort outsiders from insiders, endorses specific behaviours over others, and empowers the state to redefine the meaning of citizenship.
\end{abstract}

\footnotetext{
${ }^{1}$ Catherine Frost is an Associate Professor of Political Science at McMaster University in Hamilton, Canada.

${ }^{2}$ Elke Winter is an Associate Professor of Sociology at the University of Ottawa.
} 


\section{Introduction}

How do 'we' know our fellow citizens? ${ }^{3}$ Changes in citizenship law and policy increasingly favour identity management techniques such as biometrics, along with requirements for specific kinds of behaviour, personal circumstances, and public performance, to merit state recognition (Muller 2004). These approaches generally rely on observations in the material world, ideally using impersonal and replicable procedures. These are in contrast with an older, more personal element of citizenship. This element has been characterized in many forms over the ages, from Aristotle's civic friendship (2000) to Levinas' openness to the face of the other (1979), but is largely distinguished by activities of interpersonal engagement that, at least for these thinkers, remain prior to the state. In an increasingly securitized world, however, the reach of state authority can make such thinking seem naïve. This paper examines this assumption, and asks whether in Canada efforts to know citizens at a material, technological or procedural level have crowded out this interpersonal dimension. It argues that despite significant change, a personal and moral element remains critical to the procedures of citizenship adoption and verification. Attending to these elements provides a window on how citizenship is evolving in the twenty-first century.

How can such a question be approached? To put it another way, how does a theoretical lens concerned with knowing fellow citizens relate to the reality of citizenship policy administration? The paper begins with the idea that applying a label like "citizen" is never a straightforward activity, and that examining this process can shed light on the meaning behind it. If language is more than just words, but also involves actions and their context, then using a name requires more than rote behaviour (Wittgenstein 2008). Even in a closely administered context language users must observe and interpret the world they inhabit, and draw on complex configurations of knowledge and practice to carry out tasks. Examining how these processes come together is therefore part of understanding the concept at stake.

This paper examines the attribution of the name 'citizen' in the context of Canadian policy processes. Bringing theory and experience together in this manner has proven fruitful in citizenship studies, with legal theorists such as Ayelet Shachar (2001) and Eric Mitnick (2004) using casework to explore questions around law, while theorists such as Michael Walzer (1983), Will Kymlikca (1995) and Joseph Carens (2000) used similar methods to examine membership and identity. What Carens calls 'contextualism' begins with careful attention to a case, and draws on the unfamiliar to heighten comparison (2004). The focus for this study is on Canada, and involves two areas of law and policy that are rarely considered together - passports and naturalisation. ${ }^{4}$

\footnotetext{
${ }^{3}$ This raises the question of who 'we' are. The answer is found, in part, through state practices, although it is never a complete state monopoly and should be considered conceptually unsettled throughout. For more on the use of 'we' in the Canadian context see Winter, 2011.

${ }^{4}$ Naturalisation is generally understood as the "non-automatic acquisition of citizenship by an individual who was not a citizen of that country when he or she was born' (Liebig and Von Haaren 2011, 25). It exists in addition to ius sanguinis - citizenship by birth to parents who are members of the polity at stake - and ius soli - citizenship by birth on the polity's soil.
} 
Canada has registered significant changes in citizenship in recent years making it possible to observe its evolution. Yet observing the subtle relationship between different elements of knowledge remains a challenge. One way to go about it is by finding what satisfies a test for citizenship. The seemingly mundane experience of passport application and the exceptional situation of citizenship acquisition through naturalisation share an important quality in this regard. They both involve some test or evaluation process, one that in the normal course of affairs should not be a burden to undertake. For instance, it should not be hard to get a passport, since all a citizen needs to do is prove they are who they say they are. Naturalisation, on the other hand, is an unusual way to acquire citizenship (the majority acquire it by birth ${ }^{5}$ ). But by the time a person arrives at the final citizenship ceremony they too should have fulfilled all other expectations of naturalisation, making the ceremony itself a kind of formality.

In both cases then, the test applied is based on an assumption that the candidates already are citizens or at least citizens-in-waiting. While naturalisation is an uncommon path to citizenship, and while attention to the exception has been enlightening (Agamben 1998), we set out to investigate the norms involved in contemporary citizenship, and ask how someone is marked as insider rather than outsider. These patterns prove especially critical in the case of a description like membership, because of its heavy reliance on experience. This highlights the value of examining mundane or everyday elements of both citizenship (Hopkins and Blackwood 2011) and nationhood (Fox and Miller-Idriss 2008).

Passport applications and naturalisation processes, then, are official tests for citizenship in cases where the state generally expects to find it. What satisfies these tests can therefore tell us how knowledge around citizenship is produced in these instances. Neither a citizenship card nor a passport creates citizenship; citizenship must exist in order to be issued these documents, meaning the associated processes are looking for something that, once observed or verified, leads us either to recognize a fellow citizen or to rule someone out of consideration. But these processes conceal an important question: how do we know if we got it right? To put it another way, how do you calibrate the test? What confirms citizenship, and what invalidates it? And what knowledge practices are brought to the process? Since these practices are taken as especially authoritative in sorting insiders from outsiders, the indicators chosen have broad ramifications.

Requirements for passports and naturalisation therefore reflexively define the possibilities for future membership by specifying not only what a 'Canadian' is but also what a Canadian can be in the eyes of the state. By studying both passport issuing and naturalisation as methods 'we' use to 'know' a citizen, this paper aims to grasp their meaning beyond the political and legal level, and consider how they define and re-produce identity and the social ties between 'us.' Although we focus on Canada, this is not a claim for uniqueness. Passport photography is standardized worldwide, and many states use citizenship ceremonies to mark the transition in status. European countries, in particular, have copied North American traditions of citizenship tests, oaths, and

\footnotetext{
${ }^{5}$ Estimates are that $97 \%$ of the global population acquired citizenship by place of birth (Shachar and Hirschl 2007, 254).
} 
ceremonies. These similarities suggest that exploring the Canadian experience may prompt questions about how other states make and authenticate their own citizens.

Our findings suggest that despite efforts to secure and regulate citizenship through material or performance-based criteria, some interpersonal element remains critical to the procedures of citizenship adoption and verification in Canada. A focus on citizenship that only looks at the level of rules and exceptions, or claims that citizenship can be fully secured through data-driven or administrative measures therefore risks overstating the role of procedure or the influence of state mechanisms, and understating the significance of the social dimension and the role and responsibilities of co-citizens. In many ways this is a hopeful finding, showing that some personal or moral engagement remains part of Canadian citizenship policy. Yet it is also a vulnerability. Because personal interactions always occur in the context of a prevailing social order, they remain subject to their own frailties - from insincerity to privilege or discrimination. By drawing attention to this element we hope to temper claims around the administrative closure of citizenship, while drawing attention to the ways in which interpersonal interaction within a social order impacts on the possibilities of citizenship - for good or ill.

We start with a discussion of our theoretical premises followed by a brief overview of recent changes in the Canadian context. Second, we consider passport applications and outline the knowledge involved. Third, we examine recent changes to the Canadian naturalisation regime, and identify the knowledge practices they too invoke. Fourth, we suggest some implications for how citizenship is known, practiced and understood. We close with reflections on citizenship practices more generally.

\section{Knowing the Citizen: Some Theoretical Considerations}

We begin with the premise that citizenship, like any human institution, can change, and that it is currently changing in significant ways. Concerns around securitization and identity management illustrate one dimension of change. We also observe through this project an increasing focus on nation-building. However, features internal to identity as a concept, and to knowledge as a practice, also factor into the process and are part of our overall assessment.

With the securitisation of migration and citizenship on the rise (Nyers 2009), it is astonishing how seldom studies of citizenship and passports cross-fertilise. While the former tends to engage with the literatures on nation-building (Brubaker 1992), immigrant integration (Bloemraad 2006) and rights (Marshall 1973), the latter is often linked to topics such as border control (Torpey 2000; Salter 2008) and surveillance (Lyon 2009). In the context of securitisation, in which security concerns are used to legitimize a 'politics of the exception,' it becomes more and more important to correctly 'identify' individuals in order to distinguish between the 'good' and the 'bad,' namely those considered as 'normal' and those viewed as a 'threat' to the polity (Nyers 2009). This has given rise to yet another type of literature, namely that on digital identification technologies (Ajana 2012). 
The combination of nation-building with security and surveillance raises concerns around the future trajectory of citizenship. An emphasis on certainty, safety and political closure risks making citizenship a tool of liberal administrative states for disciplining inhabitants, reducing them to "cogs in the machinery of sovereignty" (Weber 2008, 132). It also raises the significance of the label 'citizen' and its attribution. However applying a label is especially complex where identity is concerned, because it involves two quite distinct ideas. One concerns a relationship between two or more distinct things. This is identity as "sameness with another, in a classifying objective sense." The other idea concerns continuity or integrity within a single entity. This second aspect is identity as "the self-same, in an individualizing, subjective sense" (Caplan 2001, $51)$.

Because these two aspects of identity are so divergent their means of assessment also differ. Detecting a match between distinct objects requires propositional knowledge - a truth claim that is verified by testing against facts in the world. Until recently the field of epistemology centred on an informational model built largely on propositional knowledge (Zagzebski 2012, 366). Classifying someone's identity in this manner therefore means checking some information set (identity document, biometrics, test results, etc.) against rules or records to verify a statement as true or false. Doing so establishes sameness either between the various records, or that an individual matches others already in the category. In this work, we call this mechanical knowledge because it involves a replicable comparison using discrete data drawn from the external world. In essence, it is a task that a well-programed machine can complete, although in this case it is the work of states as "sovereign machines" (Weber 2008, 132).

The informational model in epistemology has been eclipsed in recent years, however, as the focus shifts to practices and qualities that better underpin the knowledge exercise. Knowing someone as a unique individual is a case in point. What is unique can never be affirmed through comparison, so that knowing a person entails a different kind of knowledge, one based in understanding rather than information. Yet "understanding is a property of persons" not propositions (Zagzebski 2012, 364). For instance, a practice like testimony reveals a deeply social dimension to knowledge, and draws on moral practices such as sincerity, reliability and trust for its truth-value (Coady 1992). When identification draws on subjective understanding, delivered in the form of testimony, oaths and witnessing, we call this moral knowledge because the process requires qualities found only in moral subjects. Moral knowledge is not only at stake for identity-checks in passport application but also, as we will argue below, an important dimension of the "moral" politics of naturalisation (Sayad, 1982). The moral dimension raises its own concerns, since not all lives are equal subjects of concern and understanding, and epistemic trust (i.e., who we will or will not accept as sources of testimony) can be flawed, revealing engrained forms of discrimination (Fricker 2012, 348). Whereas propositional or mechanical knowledge is objective but narrow, social or moral knowledge is often all too human.

A number of changes to Canadian citizenship law and policy that took place under the mandate of Stephen Harper's Conservative Party (2006-2015) help to reveal how knowledge is organized in this area. Driven by a combination of security and patriotism, they affected critical processes where testing for citizenship is involved. For example, changes to photo and guarantor requirements were introduced, along with a new biometric 'ePassports' to digitize bearer information and showcase "iconic" national scenes (Passport Canada 2014). Responsibility for passports was also moved from the Department of Foreign Affairs, Trade and Development to 
Citizenship and Immigration Canada (Citizenship and Immigration Canada 2013), bringing naturalisation and passports together under the same department.

Changes were even more widespread regarding naturalisation policy. The Citizenship Action Plan, introduced in 2009-2010, outlined a set of integrated initiatives that aimed to "enhance the value and meaning of Canadian citizenship" (Citizenship and Immigration Canada 2010a) by strengthening civic memory, civic participation and sense of belonging to Canada. Changes included a longer mandatory residence period, tighter language requirements, a new citizenship guide and test, anti-fraud initiatives, and a modified citizenship ceremony (Winter 2015). They are discussed in greater detail below. While changes were originally administrative in nature, many became law through the Strengthening Canadian Citizenship Act, which received royal assent on June 19, 2014. This Act made Canadian citizenship harder to obtain and easier to lose (Citizenship and Immigration Canada 2014).

The currently governing Trudeau Liberals (since October 2015) are easing some of these stipulations, however not in ways that would significantly alter the argument presented here. ${ }^{6}$ While aiming to be more facilitative than punitive, their overall aim for naturalisation policy is "adjustments, not full repeal" (Griffith 2016), ${ }^{7}$ and they insist that citizenship must be a "real and meaningful" commitment (McCallum 2016). Recent measures also tighten passport requirements for dual citizens re-entering Canada (Government of Canada 2016), suggesting the emphasis on national identity and security may be a sustained trend. If so, it is increasingly important to understand the knowledge behind the name 'Canadian'.

\section{Passports in Canada}

We begin the analysis with passport applications. Passports have evolved into highly standardised documents (Torpey 2000), and the Canadian document follows the recommendations of the International Civil Aviation Organization (ICAO) like many states worldwide. Yet its routine quality belies a complex function; the passport both confirms and unsettles identity because we "pass through a moment of disappearance and examination when citizenship (being a friend) becomes our burden to prove" (Salter 2008, 337).

This experience begins with asking for the papers with which to cross a border. While Canada registers births it does not maintain a civil registry system of the kind found in many European states. This means citizens must prove themselves at point of application. Mobility rights are guaranteed in the Canadian Charter of Rights and Freedoms, but access to travel documents is not, and rights to re-entry are not easily exercised without a Canadian passport. Passports are issued at the state's discretion (Canadian Passport Order, s. 9, 20) and in 2014 Canada began refusing and revoking a passport on a number of grounds including national security (Bell 2014).

\footnotetext{
${ }^{6}$ At the time of writing, Bill C-6, An Act to amend the Citizenship Act and to make consequential amendments to another Act has just been passed by the Senate, but has not yet received royal assent.

${ }^{7}$ To give an example: while the Conservatives increased the mandatory residence period from three out of four years to four out of six years and added the requirement of physical presence to that of legal residence, the Liberals are proposing to reduce the time required to three out of five years, but to maintain the physical presence stipulation.
} 
Since the introduction of biometric passports in 2013 the document has also featured patriotic imagery that reinforces themes of security and productivity. Notably, the design includes no discernable images of living women, minorities or Indigenous people. In contrast there are six images of industry, six of military/police themes, and five of political figures or buildings. ${ }^{8}$ Then Foreign Minister John Baird, maintained the new design "tells the world who we are" ("Newly unveiled"). Given that the document is used to define national identity, and provides revocable access to constitutional rights, the means by which it is issued becomes increasingly significant.

In Canada, naturalized and natural born Canadians undergo the same process, and adult first-time applicants living on Canadian soil ${ }^{9}$ prove themselves through two main methods. The first concerns identity documents, official records, and biometric data, meaning the lion's share of work in processing an application is a straightforward fact checking and information-gathering exercise. However the application requires two more elements: the cooperation of the applicant in generating new identification information, and personal testimony from individuals who vouch for the applicant as long-term associates. Although easily overlooked, the application also relies upon the applicant's own testimony in signing the application (twice). While such testimony is ultimately turned into documentation, it originates in interpersonal (and intrapersonal) understanding, meaning there are two distinct forms of knowledge at work.

\section{Documented Identity}

Relying on document-checking as a way of knowing a citizen provides relatively clear-cut results. Yet there are limits to knowing citizens this way. Results are only as reliable as the system used to look for matches within, meaning document-checking is vulnerable to large-scale failure. Since some of the most populous countries around the world lack well-institutionalised identity systems, to the extent that the passport process in Canada relies on records from outside the country, it is vulnerable to uncertainty (Sadiq 2010, 68). The same holds true for decisions regarding naturalisation, discussed below.

Problems with identity are not limited to foreign documents. Take for instance the passport photograph. The photograph is one of the original biometric measures, and although some European states include fingerprinting, the digitized image is the chief measure recommended by the ICAO, and the primary element in what makes something a biometric passport (Epstein 2007). Photo requirements were updated in 2003 to meet facial recognition standards that require neutral expressions and strictly specify gaze and posture. The image's technological application tends to overshadow the way the photograph also functions as a kind of test, establishing the willingness of the subject to self-discipline before the camera. Passport photography, in other words, involves a kind of performance that signals a subject is fit for consideration. The fact that the requirement is imposed on subjects whose disability, illness or sheer infancy makes it all but

\footnotetext{
${ }^{8}$ Absent Canadians are represented as stone - statues for women and the disabled, and a crude stone structure for Indigenous peoples. The representational imbalance was pointed out early in the design process (Beeby, 2012). For more on the visual dimension of the passport see Frost (2017).

${ }^{9}$ All references to the Canadian passport application are to the application process for this group. The application document is available at: http://www.passport.gc.ca/form/pdfs/pptc153.pdf (Passport Canada 2016a). Subsequent renewals use a simplified application.
} 
impossible to comply, suggests that identifying Canadians, in this case, is oriented not around the detection of sameness, but around its production.

The requirement that the bearer should always match the resulting image is equally problematic, and there is evidence that expressionless photographs undermine recognition, making them "unsuitable as proof of identity" (Jenkins, White, Van Monfort and Burton 2011, 313-4, 318, 322). Beyond day-to-day variability, accidents or illness can change appearance, even alter a signature, leaving an individual at a serious disadvantage. ${ }^{10}$ In these cases a traveller would be wise to update their passport. But they are doing so precisely because they no longer match their documents. Which suggests the passport process must, at some point, be drawing upon something beyond biometric comparison as a way of knowing the applicant.

For some individuals the sameness stakes are even higher. By requiring applicants to identify with one of the traditional genders, the passport system effectively says an intersex or ambiguous-gender Canadian is either impossible, or impermissible. Notably, Australia has been issuing passports with an ' $\mathrm{X}$ ' (sex unspecified) gender designation since 2011 (Australia. Department of Foreign Affairs and Trade n.d.) and at least seven other countries have followed suit. ${ }^{11}$ Reports appeared in 2012 suggesting that Canada was looking into a similar measure (Hopper 2012). Yet at the time of writing no changes have been forthcoming, and no timeline is in place for a decision on the issue (Canadian Press 2016a). Moreover, Passport Canada is reportedly rejecting applications that use new Ontario health cards as identification, on the grounds they do not specify a gender (Canadian Press 2016b).

In sum, there are limitations to relying on a documentary or matching process as a way of knowing citizens. It proves strikingly unreliable in some countries, it involves an unnatural image of the citizen, is fundamentally out of step with our evolving nature, and creates hardship for individuals who do not align with official requirements. Given these limitations, other methods must form part of how a citizen is identified.

\section{Lives Lived}

The passport application also calls for one guarantor and two acquaintances that have known the applicant to co-sign the form. Requirements that the guarantor be from a select list of professions were dropped in 2010 in favour of a guarantor being an adult Canadian passport holder. While the change was an effort to liberalize requirements, the policy maintains the total number of witnesses at three, and ensures that in the case of guarantors only officially validated Canadians can provide this crucial testimony (Foreign Affairs, Trade and Development 2016).

This reflects an assumption about Canadians: most should be able to find a passport-holder among their long-term associates. However this may not always be the case. While the national rate of passport possession reached $70 \%$ in 2013 (the last year data was made available), the

\footnotetext{
${ }^{10}$ Consider, for instance, the Canadian woman who was stranded and temporarily jailed in Sudan in 2009 when officials felt she did not match her passport photo (Cohen 2012).

${ }^{11}$ The X-designation has been permitted under ICAO rules since its use on emergency travel documents for war refugees in the 1940s.
} 
Indigenous territory of Nunavut recorded a mere $18 \%$ while in three other provinces and another territory the possession rate is $50 \%$ or below (Passport Canada 2013). In the event that an individual cannot locate an eligible guarantor an applicant can complete a special statutory declaration before a figure legally authorised to witness oaths (Passport Canada, 2016b), substituting self-testimony for those whose acquaintances do not meet the trustworthiness standard.

The intersection of guarantors, trustworthiness and documentation points to an important tension. The evolution of state identity practices was driven by a desire to "substitute" the reliability of official records for the "uncertainties of witness testimonial" (Caplan 2001, 56; Noiriel 2001). Yet the Canadian passport system does not entirely dispense with the messy work of knowing an applicant as a unique individual. While mechanical forms of knowing like document checks, biometrics, and official records provide valuable information, Canada still relies on some degree of moral knowledge to recognise a citizen. A similar tension between the state's desire to know the (would-be) citizen and its capacity to know through the methods adopted exists in naturalisation.

\section{Naturalisation in Canada}

In contrast to the rational, material selection mechanisms at stake in modern liberal immigration policy, those involved in naturalisation policy have a tendency to operate at the symbolic level of social closure. This is particularly true in a country like Canada where a highly functional and rationally selective immigration system is in place. According to Abdelmalek Sayad, naturalisation involves a "contamination of politics by [alleged] morals" (1982, 24 our translation). He explains:

One does not tolerate the foreigner who lives within the nation but does not apply for naturalisation, because one suspects a condescending attitude - it must be out of contempt for the quality of [Canadian culture] that one would not want to be Canadian --, but one does not tolerate either to grant naturalisation to just anyone, to just anyone who requests it [...] but may not deserve it (1982, 25 our translation).

The paradox described by Sayad is also present in the Canadian naturalisation rules: On the one hand, those entering the country as immigrants are given permanent resident status and are thus citizens in waiting. ${ }^{12}$ They are entitled to stay in the country on a permanent basis even without citizenship. ${ }^{13}$ This aligns the highly exceptional situation of applying for citizenship with the more commonplace process of applying for a passport. The recent policy changes notwithstanding, access to naturalisation in Canada is fairly straightforward for the majority of applicants. To be eligible for citizenship, immigrants must have permanent resident status, must have legally resided, and been physically present in the country for three of the previous five years. They must be at least 18 years of age, display an adequate ability in English or French (new documentation/testing has been required since November 2012), and have no criminal

\footnotetext{
${ }^{12}$ Recently, Canada has made changes to this tradition by dramatically increasing the number of temporary migrants admitted each year (Pellerin 2011).

${ }^{13}$ Although we should not forget that they may be deported if they commit criminal offences.
} 
convictions in the past three years. Undergoing a formal citizenship test, they must understand the rights and responsibilities of citizenship and demonstrate some knowledge of Canadian history, values and institutions. They are also required to take a citizenship oath. Dual citizenship is allowed, thus only immigrants from countries that do not recognise dual citizenship have to renounce home country citizenship. In principle, these criteria should easily be met by many of the citizenship candidates just as passport applications must be a reasonably accessible process or risk undermining Canadians' mobility rights.

On the other hand, even out of the pool of eligible permanent residents, not just anyone can become a member by association. As implied by the quote from Sayad $(1982,25)$ above, for the polity's "amour-propre" to be satisfied, naturalisation must not only be asked for by outsiders, there must also be the possibility for this demand to be rejected. The outsider's application for citizenship is a flattering homage to the polity, its people and the nation's moral character, historical grandeur, and overall beauty. The potential for rejection underlines the exclusive and exquisite character of citizenship. Through naturalisation policy, the state acts as a gatekeeper and purposely demonstrates that it watches over more than the economic affairs of the nation, which tend to dominate immigration rules. When it comes to naturalisation, the state claims to protect the national character and, in this case, the quality of Canadianness. In principle, fulfilling this task requires an intimate moral knowledge of citizenship candidates' intentions towards the political community. In stark contrast, modern liberal states are increasingly invested in knowing prospective citizens mechanically.

In Canada, recent legal and administrative changes concern all three consecutive steps to be taken in the naturalisation process: the citizenship application, the citizenship exam, and the citizenship ceremony. We will discuss them below.

\section{Citizenship Application Documents}

Citizenship candidates must demonstrate that they have legally resided in the country for the appropriate amount of years, provide proof of physical presence (since 2014), and undertake a standardised language test (since 2012) ${ }^{14}$ before they can apply for citizenship. To prove physical presence in the country, a rigorous 'residence questionnaire' was introduced (May 2012). The detailed four-page form must be accompanied by proof such as tax returns, pay stubs, and airline tickets to document even brief absences (Citizenship and Immigration Canada 2012b). ${ }^{15}$

The Canadian government uses both physical residence and adequate language skills as proofs of successful integration. However, both can only serve as proxies of the latter. Legal residence

\footnotetext{
${ }^{14}$ The types of documents accepted as proof of competency include "the results of a CIC-approved third-party test; or the evidence of completion of secondary or post-secondary education in English or French; or the evidence of achieving the appropriate language level in certain government-funded language training programs" (Citizenship and Immigration Canada 2012a). Previously, citizenship candidates' language skills were verified at the moment of the citizenship exam and by means of the latter, as well as through their interaction with CIC representatives. Bill C6 does not foresee any changes to this.

${ }^{15}$ Under the proposed Bill C-6, adult applicants continue to be required to file Canadian income taxes. It is, however, unclear what has become of the arduous residence questionnaire.
} 
alone - and even physical presence within Canada - does not imply that an individual has social contacts with others and has adopted so-called 'Canadian values.' The same holds true for the standardised language requirements. As Derwing and Waugh $(2012,26)$ remind us, "raising language requirements at the selection stage will not in itself guarantee the integration of newcomers." Rather, "sustained opportunities for learners to interact with speakers of an official language" are necessary even for immigrants with high test scores in an official language in order to acquire the soft skills and culturally based "linguistic pragmatics" that will allow them to "fit in". In other words, here 'cheap' mechanical verification measures are used as substitutes for moral knowledge of 'real' integration. ${ }^{16}$

\section{Citizenship Exam}

A new citizenship study guide was first introduced in November 2009. Discover Canada: The Rights and Responsibilities of Citizenship is longer than its precursor. It contains much more prescriptive and normative language, insists on the importance of respecting "Canadian values" and denounces "barbaric cultural practices" such as honour killings, female genital mutilation, and forced marriage (Citizenship and Immigration Canada 2011a). It also places greater emphasis on Canadian history generally, and specifically on military history and the place of the British monarchy in Canada (Citizenship and Immigration Canada 2009). Consistent with the citizenship guide's new content, the government created a new citizenship test that came into effect on March 15, 2010 (Citizenship and Immigration Canada 2010b). As with the previous version of the test, the new exam consisted of 20 multiple-choice questions to be answered within 30 minutes. The score required to pass, however, was raised from $60 \%$ to $75 \%$ (Citizenship and Immigration Canada 2011d). A few months after the new test's introduction, there was a marked increase in the failure rate from between $4 \%$ to $8 \%$ for the old test to nearly $30 \%$ for the new one (Presse canadienne 2010). In response, the authorities revised the test and its degree of difficulty in order to reduce the failure rate to 20\% (Griffith 2013; Presse canadienne 2010). ${ }^{17}$

This is one of the clearest examples that the changes in Canada's naturalisation regime take place at a symbolic rather than a factual or material level: although the government wants to raise the stakes in the naturalisation process by making the citizenship study guide longer and the exam more difficult to pass, it does not intend this mechanism to serve as a dramatic form of social closure. While Canada wants to be asked to grant citizenship, it is actually interested in accepting new members. The new rules are predominantly meant to instil in newcomers a patriotic love for the monarchy and the military, knowledge about Canadian history, democratic values, including gender equality.

\footnotetext{
${ }^{16}$ The question whether or not the state should be testing new citizens' 'good morals' and loyalty to Canada cannot be addressed here.

${ }^{17}$ While a major revision of Discover Canada has not been proposed (neither in legislation nor in the Liberal platform or the Minister's mandate letter), it is expected that some nuances may change; the new Liberal Minister has expressed concerns regarding the degree of emphasis on the War of 1812 and references to "barbaric cultural practices." Under Bill C-6, the knowledge requirement (citizenship test) must also be met in English or French, not through an interpreter.
} 
However, here too, mechanical knowledge (a multiple choice test) is used as a substitute for a more sincere moral understanding of the newcomers' religious and social values, their attitude towards the monarchy and their loyalty to Canada more generally.

\section{Citizenship Ceremony}

Two regulations changed the tone of the citizenship ceremony between 2011 and 2015. First, there was a much stronger presence of the military. At least one past or present member of the Canadian Forces was to be present and to be recognized by the citizenship judge or ceremony presider during every ceremony (Citizenship and Immigration Canada 2011e). Members of the Order of Military Merit could also preside over citizenship ceremonies, a role that was usually reserved for citizenship judges (Citizenship and Immigration Canada 2011b). Second, the citizenship certificate was only awarded to those swearing allegiance with their faces uncovered. The goal of the regulation was to allow citizenship judges to confirm that the person is actually reciting the oath, insisting on the public nature of the act and the necessity that new citizens' allegiance to their new country be clearly visible and understandable (Kenney 2011). In the federal election campaign of 2015, it became clear that the targeted individuals were Muslim women wearing a face veil, the niquab or burqa. The Federal Court of Canada has since declared that bans on face veils worn for religious reasons were contrary to Canadian Law. The present Liberal government respects that position.

The issue of who attends and leads the ceremony is like the extended citizenship study guide in that it aims at the inculcation of specific values. The second example above, concerning the face veil issue, demonstrates more sharply how something that could be quintessential moral knowledge (one testifies on one's own behalf, knowing one's own intentions are good) is largely just an orchestrated performance. In the case of the citizenship oath the check seemed to rely more on recorded observation than on the delivery of the oath itself. Although the obligation to unveil in public when swearing the citizenship oath was eliminated from the Canadian political playing field for now, the widespread obsession with veiled Muslim women in Western liberal societies suggests that mechanical knowledge is taken or mistaken for 'the real thing.' At the very least, the two kinds of knowledge blur: the state wants both some deeper but difficult to observe moral qualities and a secure way of checking that actual or potential citizens do what 'we' require. As such, it pretends to know that naturalising Muslim women are 'emancipated' if they do not wear a face veil, and that they are sincere if one can see how they move their lips in pronouncing the citizenship oath. While the state does not know anything about their lives, relationships and religious beliefs, it pretends that it can verify their potential to be good citizens by the mechanical check of oath recitation. Yet if taken as a purely a mechanical operation, the citizenship oath is at risk of being drained of the meaning the ceremony seeks to affirm.

In sum, naturalisation involves a strange identity-check: citizenship candidates having undergone the selection process in immigration, and having spent the required legal time of residence in Canada without criminal convictions, ask for full inclusion in the national community. The state having granted these individuals permanent resident status has an interest in normalising their status and in naturalising them. However, the state now asks: How do we know that these persons are/have become 'us' over the past couple of years? How do we know that they are the deserving citizens that they claim to be? The naturalisation process is thus an institutionalised 
rite of passage (Fassin and Mazouz 2009), where the state-in the name of the national community - insures both the adequacy of its past decisions (to grant immigration) and the worthiness of the citizenship applicants.

\section{Knowing the Citizen: A multi-faceted process}

While the aim of naturalisation and passport-issuing is to recognise the citizen, tensions exist between knowing citizens in concrete, externally-verifiable and mechanical ways, and knowing them in social or moral ways. Indeed, the tension between these two ways of knowing the citizen may help explain peculiarities in the process. For example, the readiness to substitute selftestimony for official documents or to modify citizenship test requirements that prove difficult to meet. Willingness to modify the process suggests 'we' are, in some way, reasonably certain that we are dealing with citizens or proto-citizens. This suggests that knowing a citizen is a multifaceted process. Three dynamics deserve particular attention: how insiders are distinguished from outsiders, how individuals are recognised as one of 'us,' and how these processes redefine what the attribute 'Canadian' means.

\section{Insiders/Outsiders}

The passport application sorts insiders from outsiders primarily by means of an officially documented biography; a life lived under the gaze of the state. Individuals must be willing to cooperate with these requirements, including new measures to collect and store existing information. It also requires individuals to be literate, self-aware and good record-keepers, in a sense maintaining a Weberian bureaucracy in miniature. However there is also a moral dimension to the process. A Canadian is known by their stable self-image, and sustained relationships with other well-documented, trustworthy Canadians.

Yet what about when someone's documents and guarantors check out, but security concerns result in a denial of their passport application? In this case both mechanical and moral knowledge, in a sense, fail. Insofar as the state refuses to acknowledge this citizen as its own to foreign governments, their citizenship is unlike that of 'normal' Canadians. Ultimately then, a Canadian is someone the state considers safe not only based on what they know from their past, but also what they expect in their future. Yet note that expectation is a hallmark of uncertainty rather than knowledge.

Naturalisation is the process that allows outsiders to become insiders, making it a citizenship process that applies only to outsiders. It marks a stark contrast with the experience of the vast majority of citizens who are insiders by virtue of birth location (jus soli) or through parental citizenship (jus sanguinis). In both cases, as Ayelet Shachar (2009) reminds us, status depends upon the accident of birth. What is remarkable here is the absence of moral knowledge involved; natural-born insiders are tested for neither their morals, nor their capacity to be 'good Canadians.' This betrays an implicit assumption that accidental, involuntary membership is somehow reliably sincere while naturalisation is an effort to emulate or substitute for this 'natural' moral connection. The pursuit of moral knowledge about the new citizen, explains aspects of the naturalisation process that might otherwise seem trivial or peculiar, such as the emphasis on the 
observable delivery of the oath.

\section{One of 'us'}

The passport process assumes that Canadians live a socially engaged lifestyle, likely involving employment and/or social services that produce verifiable documentation. It also requires Canadians to self-neutralize for the camera, and declare a gender identity that matches their medical exam. Engagements based on trust, exchange, submission and gender therefore mark a citizen as one of 'us.'

Still, the state is operating with a flawed assumption - that Canadians are static in certain aspects of their identity. Since this does not hold true in many cases, the process is supplemented with personal testimony (including attestation through signature). Personal testimony has two important advantages. First, it grasps the coherence of a person even through profound change; second, real world co-existence is harder to fake than documents. Since any use of testimony necessarily calls upon sincerity and trust, this reveals a moral element at the heart of the Canadian identification system.

However testimony poses its own concerns. Our readiness to trust some more than others tells us a great deal, as these patterns "tend to imitate relations of social power at large in the society," (Fricker 2012, 340) and "must be regarded as seriously defective both epistemically and ethically." (Ibid, 348) If so, the passport application shows how moral knowledge, when based on "systematic testimonial injustice" (Ibid, 348) becomes a form of privilege. To put it another way unless you have certain kinds of associates, including people with means and motive for international travel, your standing within the Canadian community will be that much less secure.

Stranger still, the naturalisation process aims to cultivate some degree of insecurity surrounding the grant of citizenship. To go back to Sayad's (1982) observation, naturalisation is indeed a contamination of politics by morals. While permanent residents who have been selected through the immigration process are already factual insiders - they live in Canada, work in Canada, pay taxes in Canada - they are not yet 'one of us.' In order to be elevated from denizenship to citizenship, they have to undergo a second identity-check, which imposes yet other criteria than those that they were selected upon for the purpose of immigration. While having been selected for purely utilitarian purposes (in the case of skilled workers - refugees are an exception), the state wants to be assured that applicants are not equally utilitarian about their Canadian citizenship. The state does not want 'citizens of convenience', rather it wants newcomers who demonstrate that they have become 'one of us' by knowing 'our' history the 'right' way, by speaking 'our' language, by signing up for the army and potentially defending 'our' country, which by then would indeed also be theirs. The switch from pragmatic considerations to moral ones points to an important shift. We may know a good candidate for immigration by their skills or financial assets, but we know a citizen by their moral intentions.

This assumes, however, that the newcomers have an exceptionally positive experience in Canada over their years as permanent residents, in order to form these personal bonds and moral attachments. It also assumes that the state has developed the right tools for knowing the 
truthfulness of those who apply for membership. Finally, proving an applicant has become 'one of us' is a difficult exercise when the benchmark is not fixed. While 'Canadian values' are often referred to in government documents and speeches, one is hard pressed to find anything more specific than "the importance of democracy, the rule of law, and fundamental human rights" (Standing Committee on Citizenship and Immigration 2013). Add to this that French-English bilingualism and multiculturalism remain official parts of Canadian diversity, it is difficult for the citizen-to-be to know with which segment of 'us' he or she is required to morally engage.

\section{Redefining Canadians}

While the passport process is focused on existing rather than future Canadians, developments in the application also reflect a view of how Canadian life is evolving. For instance, Canadians are increasingly conceived of as fear-driven, putting security ahead of privacy or rights equality. Similarly, the new ePassport design attempts to re-imagine what Canadians consider 'iconic.' According to this logic, a Canadian is someone inspired by scenes that primarily feature white men in political, industrial or military settings.

In the case of naturalisation, the process also reveals more about 'us' as insiders than about 'them' as outsiders. Since the moral sincerity of the citizenship candidate is difficult to discern, and since the Canadian government actually wants permanent residents to become citizens, it is worth asking why the state spends huge amounts of money in administering this kind of second identity check? Should permanent residency transition automatically into citizenship after a set amount of time? While this would have the virtue of efficiency it would eliminate a crucial element of the naturalisation process focused on moral identity.

The diverse elements of the naturalisation process showcase how the state wants Canadian society to be seen. This is specifically the case with the Canadian citizenship study guidewhose content has changed dramatically, from peacekeeping to military issues, from the welfare state to one's own responsibility for one's economic well-being, from community involvement to Western democratic values (specifically gender equality, voting and obeying the law) - but also with the citizenship oath, the revamped citizenship ceremony, and physical residence rules. In sum, through naturalisation policy, the state aims to define 'good (moral) citizenship,' but stages and tests it in a fairly mechanical way.

In cases where the capacity of the chosen (mechanical) method is in doubt, fellow citizens often bureaucrats as in the case of oath recitation or sworn testimony - are called upon to assist with gaining moral knowledge. But here too moral knowledge is susceptible to its own problems. Take for example the introduction of a tip line that invites citizens to call in and denounce their (would-be) compatriots if they suspect citizenship fraud (Citizenship and Immigration Canada 2011c). ${ }^{18}$ In this case, the state uses 'ordinary Canadians' to reinforce its definition of good moral character. At the same time, it instils a particular version of 'good' citizenship in all of those who participate.

\footnotetext{
${ }^{18}$ At time of writing, this tip line is still operational.
} 


\section{Conclusion}

This look at citizenship practices proved to be revealing. Our investigation confirms a troubling rise in fact-checking, document-matching and standardised forms of testing and authentication. In fact, it matters little whether or not some of the Conservative changes to Canada's citizenship regime are currently being undone by the Trudeau Liberals. Under both governments naturalisation and passport applications mostly involve mechanical knowledge, which is used as an unconvincing substitute for the moral knowledge that would be necessary to confirm actual and prospective citizens' identity and Canadianness. Yet mechanical knowledge has little room for the nuances and varieties of life. The state's obsession with sorting citizens into mutually exclusive categories such as safe/unsafe, deserving/undeserving, authentic/fake or trustworthy/untrustworthy produces a system that is riddled with errors and inconsistencies. Here, our discussion joins with much of the recent scholarship on securitization and the rise in biometrics (Lyon 2009; Ajana 2012; Epstein 2007).

The problem with mechanical knowledge is that it faces limitations around knowing Canadians as unique individuals. Given the right circumstances, it is both easily deceived and easily confused, because qualities like appearance or material circumstances change all the time. The fascination with fixed biometrics, for instance, is out of step with this reality, offering only a "crude expression of the dream of perfect information" (Currah and Mulqueen 2011, 567). The process becomes even more absurd when the object of examination is a carefully scripted performance, such as the enforced fealty of citizenship ceremonies or the passivity of the passport photograph. When poor results of an 'objective' knowledge test mean the test failed rather than the candidates, we have to ask what else is informing state decision-making? The problem, it seems, is that the state is trying to detect a moral quality such as trustworthiness or sincerity by dictating mechanical, observable actions. By insisting candidates 'sit this way,' or 'speak these words' it tries to find in Canadians a quality that the state can never meaningfully detect.

These inadequacies point towards the importance of understanding as a form of knowledge. While less exact it is more comprehensive, and especially well-suited to knowing others in a substantive way (Zagzebski 2012). Relationships of understanding become the basis for testimony in passport applications, and provide the rationale behind residency and language requirements in naturalisation. Canadians also testify for themselves - in signing their passport applications, and taking oaths of citizenship. Both actions receive careful scrutiny of course, but as fundamentally moral actions, there is no way for propositional knowledge or mechanical checking to ever completely confirm their reliability. Which is why the Canadian state turns to social behaviours and relationships that take place outside the reach of state machinery to complete the process for passports and naturalisation.

Admittedly Canada, like other states worldwide, has made efforts to shrink the political significance of a form of knowledge it can neither participate in nor directly control. Concerns around the changing nature of citizenship are therefore quite real. Yet if a combination of mechanical and moral ways of knowing helps form a picture of the individual that secures their recognition in the eyes of the state, then the trajectory of citizenship can only bend so far towards closure. The continued significance of social and moral dynamics to the administration of 
citizenship, even within a state that prioritizes security, reinforces the importance of attending to these dynamics.

The use of the passport and naturalisation to celebrate particular values also reveals the state's desire to not just learn from, but also shape, the moral life of Canadians, making safety and productivity central values. Yet insofar as some aspect of citizenship remains vested in individuals, and insofar as the state reaches out to them in order to learn more about present and potential citizens, it will not be a simple matter to attain complete closure around these values. While still critical then, this view allows for a less pessimistic view than usually informs studies of citizenship securitisation (e.g. Nyers 2009). Despite being a highly standardised processes, neither naturalisation nor passport issuing are conducted in a detached, mechanical way, and our analysis shows that currently, at both ends of the citizenship process, a mix of methods are involved to ensure an individual is 'one of us.'

Nothing in this analysis should be taken as suggesting that moral and social dynamics are without their dangers, however. Yet as long as they are part of the system, and are likely to remain so, it's critical to acknowledge and examine their role. The reliance on personal and moral qualities to validate citizenship adds an amorphous element to how citizenship is enacted in Canada. This element can be the source of concern if it overreaches itself and sets expectations for newcomers that native-born Canadians do not face, or imposes a concept of Canadian life that is difficult for some to live up to because of personal circumstances. Who gets trusted can become a proxy for social privilege, and there are cases, such as the citizenship tip line, where alleged moral knowledge is abused by the state in the name of advancing freedom, equality and security. Equally often however, moral knowledge gained through personal testimony destabilises the 'mechanical' category-fixing exercise inherent to both passport and naturalisation applications. It shows that fellow citizens often know an individual better than the state apparatus can, and may serve to humanize the citizenship process in promising ways. This is an important lesson for politicians and policy makers at times when concerns about security and expediency often stand in the way of more substantial ways of knowing. 


\section{REFERENCES}

Agamben, Giorgio.1998. Homo Sacer: Sovereign Power and Bare Life. Daniel Heller-Roazen (trans.). Stanford, CA: Stanford University Press.

Ajana, Btihaj. 2012. "Biometric citizenship,” Citizenship Studies 16 (7): 851-870.

Australia. Department of Foreign Affairs and Trade. n.d. "Sex and gender diverse passport applicants." https://www.passports.gov.au/passportsexplained/theapplicationprocess/eligibilityoverview/Pages/ch angeofsexdoborpob.aspx [Accessed 9 December 2016].

Beeby, Dan. 2012. “ePassport Images Under Fire for Lack of Diversity,” The Huffington Post, 31 October. http://www.huffingtonpost.ca/2012/10/31/epassport-canada-photosimages_n_2051975.html [Accessed 9 December 2016].

Bell, Stewart. 2014. "Canadian government begins invalidating passports of citizens who have left to join extremist groups," National Post, 20 September.

http://news.nationalpost.com/news/canada/canadian-government-revoking-passports-of-citizenstrying-to-join-extremist-groups [Accessed 12 December 2016].

Bloemraad, Irene. 2006. Becoming a Citizen: Incorporating Immigrants and Refugees in the United States and Canada. Berkeley, CA: University of California Press.

Brubaker, Rogers. 1992. Citizenship and Nationhood in France and Germany, Cambridge, MA: Harvard University Press.

Canadian Passport Order. SI/81-86. http://laws.justice.gc.ca/PDF/SI-81-86.pdf [Accessed 14 January 2015].

Canadian Press. 2016a. "Gender-neutral ID issues on Ottawa's radar for more than a year," CBC News, 5 July. http://www.cbc.ca/news/politics/gender-neutral-id-issues-1.3664821 [Accessed 17 November, 2016].

Canadian Press. 2016b. "Ontario's gender-neutral health cards not a valid ID to obtain a passport," CTV News, 4 August. http://toronto.ctvnews.ca/ontario-s-gender-neutral-health-cards-not-a-valid-id-toobtain-a-passport-1.3015409 [Accessed 17 November 2016].

Caplan, Jane. 2001. “"This or That Particular Person': Protocols of Identification in Nineteenth Century Europe." In Jane Caplan and John Torpey (eds.) Documenting Individual Identity. Princeton, NJ: Princeton University Press, 49-66.

Citizenship and Immigration Canada. 2009. Backgrounder: Substantial changes to the Citizenship Study Guide: How Discover Canada differs from A Look at Canada. http://www.cic.gc.ca/english/department/media/backgrounders/2009/2009-11-12a.asp [Accessed 6 December 2012]. 
Citizenship and Immigration Canada. 2010a. Annual Report to Parliament on Immigration, 2010. http://www.cic.gc.ca/english/pdf/pub/immigration2010_e.pdf [Accessed 16 December 2016].

Citizenship and Immigration Canada. 2010b. "New citizenship test -- operational instructions." Operational Bulletin, no. 203, 26 April. http://www.cic.gc.ca/english/resources/manuals/bulletins/2010/ob203.asp [Accessed 14 October 2012].

Citizenship and Immigration Canada. 2011a. Discover Canada: The Rights and Responsibilities of Citizenship, Minister of Public Works and Government Services Canada. http://www.cic.gc.ca/english/pdf/pub/discover.pdf [Accessed 13 March 2011].

Citizenship and Immigration Canada. 2011b. News Release -- Members of the Order of Military Merit can preside at citizenship ceremonies, Ottawa: 18 October. http://news.gc.ca/web/articleen.do?nid=629459 [Accessed 15 December 2016].

Citizenship and Immigration Canada. 2011c. News Release -- Report citizenship fraud via new tip line, Ottawa: 8 September. http://news.gc.ca/web/article-en.do?nid=621879 [Accessed 15 December 2016].

Citizenship and Immigration Canada. 2011d. News Release -- Updated Discover Canada citizenship study guide now available, Vancouver: 14 March. http://news.gc.ca/web/article-en.do?nid=595679 [Accessed 15 December 2016].

Citizenship and Immigration Canada. 2011e. "Operational instructions related to the participation of members of the Canadian Forces and veterans at citizenship ceremonies," Operational Bulletin, no. 296, 15 April. http://www.cic.gc.ca/english/resources/manuals/bulletins/2011/ob296.asp [Accessed 15 October 2012].

Citizenship and Immigration Canada. 2012a. News Release -- Minister Kenney announces new language rules for citizenship applicants, Ottawa: 28 September, http://news.gc.ca/web/articleen.do?nid=697099 [Accessed 15 December 2016].

Citizenship and Immigration Canada. 2012b. Residence Questionnaire -- Questionnaire sur la residence. http://www.img.com.vn/media/37408/cit0171 residence questionnaire.pdf. [Accessed 1 May 2013; on 16 December 2016 this link is no longer active].

Citizenship and Immigration Canada. 2013. News Release - Improving Passport Services for Canadians. Ottawa, 8 May. http://www.marketwired.com/press-release/improving-passport-services-forcanadians-1788496.htm [Accessed 7 November 2016].

Citizenship and Immigration Canada. 2014. Government welcomes "Assent of Bill C-24. Ottawa: 19 June. http://news.gc.ca/web/article-en.do?\&nid=859509 [Accessed 20 June 2014].

Coady, C.A.J. 1992. Testimony: A Philosophical Study. Oxford: Clarendon Press. 
Cohen, Tobi. 2012. "Government on the hook for \$1.5 million in legal costs for abandoning woman in Kenya," National Post, 8 November. http://news.nationalpost.com/news/canada/government-on-thehook-for-1-5-million-in-legal-costs-for-abandoning-woman-in-kenya [Accessed 24 February 2016].

Currah, Paisley and Tara Mulqueen. 2011. "Securitizing Gender: Identity, Biometrics, and Transgender Bodies at the Airport," Social Research 78 (2): 557-82.

Derwing, Tracey M. and Erin Waugh. 2012. "Language Skills and the Social Integration of Canada's Adult Immigrants," IRPP Study (Montreal Institute for Research on Public Policy) 31: 1-36. http://irpp.org/fr/research-studies/study-no31/ [Accessed 17 January 2015].

Epstein, Charlotte. 2007. "Guilty Bodies, Productive Bodies, Destructive Bodies: Crossing the Biometric Border,” International Political Sociology 1 (2): 149-164.

Fassin, Didier and Sarah Mazouz. 2009. "What is it to Become French? Naturalisation as a Republican Rite of Institution," Revue française de sociologie 5 (50): 37-64.

Foreign Affairs, Trade and Development Canada. 2016. "Passport Canada - New Guarantor Policy and Directive on Loss of Citizenship." Modified June 27. http://international.gc.ca/gacamc/publications/atip-aiprp/assessments-evaluation/guarantor_citizenshiprepondants_citoyennete.aspx?lang=eng. [Accessed 9 December 2016].

Fox, Jon E. and Cynthia Miller-Idriss. 2008. “Everyday Nationhood,” Ethnicities 8 (4): 536-76.

Fricker, Miranda. 2012. "Epistemic Injustice and a Role for Virtue in the Politics of Knowing." In John Greco and John Turri (eds.) Virtue Epistemology: Contemporary Readings. Cambridge, MA: MIT Press, 329-50.

Frost, Catherine. 2017. "Disempathy and emotional witnessing in passport photography," InTensions 8 Autumn/Winter 2017.

Government of Canada. 2016. "Dual Canadian citizens need a valid Canadian passport." Modified 2 November. http://www.cic.gc.ca/english/visit/dual-canadian-citizens.asp [Accessed 7 November 2016].

Griffith, Andrew. 2013. Policy Arrogance or Innocent Bias: Resetting Citizenship and Multiculturalism. Ottawa: Anar Press.

Griffith, Andrew. 2016. "Canadian Citizenship: 'From Harder to Get and Easier to Lose' to a New Balance." Presentation at "Getting Results: Migration, Opportunities, and Good Governance," $18^{\text {th }}$ National Metropolis Conference, Toronto, 3-5 March.

Jenkins, Rob, David White, Xandra Van Monfort and A. Mike Burton. 2011. "Variability in photos of the same face," Cognition 121 (3): 313-323.

Kenney, Jason. 2011. Speaking notes for the Honourable Jason Kenney, P.C., M.P. Minister of Citizenship, Immigration and Multiculturalism, Montreal: December 12. 
http://www.cic.gc.ca/english/department/media/speeches/2011/2011-12-12.asp [Accessed 15 October 2012].

Liebig, T. and F. Von Haaren. 2011. "Citizenship and the Socio-economic Integration of Immigrants and their Children: An Overview across European Union and OECD Countries." In Naturalisation: A Passport for the Better Integration of Immigrants? Paris: OECD Publishing, 24-65.

Lyon, David. 2009. Identifying Citizens: ID Cards as Surveillance. Cambridge: Polity.

Marshall, T.H. [1949] 1973. "Citizenship and Social Class.” In Class, Citizenship and Social Development. New York: Doubleday, 71-134.

McCallum, John. 2016. Speaking notes for the Honourable John McCallum, P.C., M.P., Minister of Immigration, Refugees and Citizenship at an announcement regarding proposed amendments to the Citizenship Act, Immigration, Refugees and Citizenship Canada, Ottawa: 25 February. http://news.gc.ca/web/article-en.do?nid=1041839. [Accessed: 15 May 2016].

Muller, Benjamin J. 2004. "(Dis)Qualified Bodies: Securitization, Citizenship and 'Identity Management," Citizenship Studies 8 (3): 279-94.

Noiriel, Gérard. 2001. "The Identification of the Citizen: The Birth of Republican Civil Status in France." In Jane Caplan and John Torpey (eds.) Documenting Individual Identity. Princeton, NJ: Princeton University Press, 28-48.

Nyers, Peter (ed.). 2009. Securitizations of Citizenship. Milton Park, New York: Routledge.

Passport Canada. 2016a. "Adult General Passport Application." http://www.cic.gc.ca/english/passport/forms/pdf/pptc153.pdf [Accessed 9 December 2016].

Passport Canada. 2016b. "References and guarantors for passport and travel documents." Modified November 11. http://passport.gc.ca/info/section2.aspx?lang=eng. [Accessed 9 December 2016].

Passport Canada. 2014. “The Canadian ePassport.” Modified September 5. http://www.ppt.gc.ca/eppt/ [Accessed 9 December 2016].

Passport Canada. 2013. Annual Report: 2012/2013. http://www.cic.gc.ca/english/resources/publications/passport-ar/2012/index.asp [Accessed 9 December 2016].

Presse canadienne. 2010. "En bref: Fort taux d'échec au nouvel examen de la citoyenneté," Le Devoir, 29 November, p. A4.

Pellerin, Hélène. 2011. "De la migration à la mobilité: changement de paradigme dans la gestion migratoire. Le cas du Canada," Revue européenne des migrations internationales, 27 (2): 57-75.

Sadiq, Kamal. 2010. Paper Citizens: How Illegal Immigrants Acquire Citizenship in Developing Countries. Oxford: Oxford University Press. 
Salter, Mark. 2008. "When the exception becomes the rule: Borders, sovereignty, and citizenship," Citizenship Studies 12 (4): 365-80.

Sayad, Abdelmalek. 1982. "La naturalisation, les conditions sociales et sa signification chez les immigrés algériens: 2è partie, 'La naturalisation comme rapports de forces'," GRECO 13: Recherches sur les migrations internationales, 4-5: 1-55.

Shachar, Ayelet. 2009. The Birthright Lottery: Citizenship and Global Inequality. Cambridge, MA: Harvard University Press.

Shachar, Ayelet, and Ran Hirschl. 2007. "Citizenship as Inherited Property," Political Theory 35 (3): 253 87.

Torpey, John. 2000. The Invention of the Passport. Cambridge: Cambridge University Press.

Hopper, Tristin. 2012. “Genderless passports 'under review' in Canada.” National Post, 8 May, http://news.nationalpost.com/news/canada/genderless-passports-under-review-in-canada [Accessed 12 December 2016].

Weber, Cynthia. 2008. "Designing safe citizens,” Citizenship Studies 12 (2): 125-42.

Winter, Elke. 2015. Report on Citizenship Law: Canada, EUDO Citizenship Observatory, Florence (IT), http://eudo-citizenship.eu/country-profiles/?country=Canada. [Accessed 14 December 2016].

Winter, Elke. 2011. Us, Them and Others: Pluralism and National Identity in Diverse Societies. Toronto: University of Toronto Press.

Wittgenstein, Ludwig. 2008. Philosophical Investigations. Malden, MA: Blackwell Publishing.

Zagzebski, Linda. 2012. "Recovering Understanding.” In John Greco and John Turri (eds.) Virtue Epistemology: Contemporary Readings. Cambridge, MA: MIT Press, 351-93. 
Published by the Centre for European Studies at Carleton University, Ottawa, Canada Available online at: journals.carleton.ca/rera/index.php/rera

RERA is an electronic academic peer-reviewed journal. Topics relate to the European Union, its Member States, the former Soviet Union, and Central and Eastern Europe. The journal is a joint project supported by the Canada-Europe Transatlantic Dialogue - a cross-Canada research network supported by the Social Sciences and Humanities Research Council of Canada (SSHRC) - along with the Institute of European, Russian and Eurasian Studies (Carleton University) and its associated research unit, the Centre for European Studies.

RERA aims to provide an accessible forum for research, to promote high standards of research and scholarship, and to foster communication among young scholars.

\section{Contact:}

Carleton University

The Centre for European Studies

1103 Dunton Tower

1125 Colonel By Drive

Ottawa, ON K1S 5B6

Canada

Tel: +01 613 520-2600 ext. 3117; E-mail: rera-journal@ carleton.ca

\section{Creative Commons License}

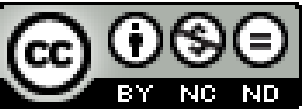

creativecommons.org/licenses/by-nc-nd/3.0

This Working Paper is licensed under a Creative Commons Attribution-Non-CommercialNo Derivs 3.0 Unported License (CC BY-NC-ND 3.0).

Articles appearing in this publication may be freely quoted and reproduced, provided the source is acknowledged. No use of this publication may be made for resale or other commercial purposes.

ISSN: 1718-4835

(C) 2017 The Author(s) 